\title{
OPTIMALISASI PENGGUNAAN ALAT KESELAMATAN KERJA TERHADAP TENAGA KERJA BONGKAR MUAT GUNA MENUNJANG PROSES BONGKAR MUAT DI PELABUHAN SEMEN INDONESIA TUBAN
}

\author{
Erika Dyah Savitria dan Andy Wahyu Hermanto ${ }^{\text {b }}$ \\ ${ }^{a}$ Taruni Program Studi KALK PIP Semarang \\ ${ }^{\mathrm{b}}$ Dosen Program Studi KALK PIP Semarang
}

\begin{abstract}
ABSTRAK
Bongkar muat adalah salah satu aktivitas penting di pelabuhan. Bahkan, ada banyak kegiatan pelabuhan seperti bongkar muat, cargodoring, penerimaan atau pengiriman. Pelabuhan Semen Indonesia Tuban adalah spesialis dalam bongkar muat semen. Masalah yang dihadapi oleh Pelabuhan Semen Indonesia Tuban adalah tidak optimalnya penggunaan peralatan keselamatan. Pengamatan ini bertujuan untuk mengetahui bagaimana menggunakan peralatan keselamatan bagi karyawan bongkar muat, dampak kurang optimal penggunaan peralatan keselamatan dan upaya Pelabuhan Semen Indonesia untuk mengoptimalkan penggunaan peralatan keselamatan.

Penelitian ini menggunakan metode kualitatif deskriptif untuk menggambarkan objek. Metode ini digunakan untuk mendapatkan semua deskripsi jelas tentang menggunakan peralatan keselamatan bagi karyawan bongkar muat di Pelabuhan Semen Indonesia Tuban. Untuk menentukan prioritas masalah dalam penyelesaiannya, penulis menggunakan metode pendekatan seperti fishbone analysis dan fault tree analysis.

Berdasarkan hasil penelitian, penggunaan peralatan keselamatan bagi karyawan bongkar muat dalam rangka mendukung proses pemuatan bongkar muat di Pelabuhan Semen Indonesia Tuban tidak optimal. Masih ditemukan karyawan bongkar muat tidak memakai peralatan keselamatan. Efek yang kurang optimal menggunakan peralatan keselamatan itu berarti tidak terjamin kesehatan dan keselamatan karyawan, meningkatkan risiko kecelakaan kerja, kehilangan penghasilan karyawan, mengubah jadwal bongkar muat di pelabuhan, perlahan-lahan pada proses penggantian karyawan baru, dan menghambat proses produksi semen di pelabuhan. Upaya yang harus dilakukan adalah melakukan koordinasi dan komunikasi terkait pekerjaan karyawan dalam bongkar muat, mengingat peraturan dalam menggunakan peralatan keselamatan, melakukan praktik tentang peralatan kesehatan dan keselamatan, dan mengadakan rapat keselamatan untuk karyawan bongkar muat.
\end{abstract}

Kata kunci: optimalisasi, peralatan keselamatan, karyawan bongkar muat, Pelabuhan Semen Tuban

\section{PENDAHULUAN}

Seiring perkembangannya teknologi dan semakin pesatnya perkembangan dunia pelayaran maka banyak perusahaan-perusahaan yang menggunakan jasa transportasi darat, transportasi udara, dan terutama menggunakan transportasi laut.
Berdasarkan fakta di atas maka aktivitas di pelabuhan semakin meningkat seperti bongkar muat barang dari kapal ke dermaga (stevedoring), bongkar muat barang dari dermaga ke kapal (cargodoring), atau perpindahan barang dari dermaga pelabuhan ke gudang (receiving atau delivey). Tetapi untuk memperlancar dan mempermudah proses 
bongkar muat tersebut diperlukan tenaga kerja bongkar muat. Hal ini merupakan faktor pokok dari penunjang aktivitas proses bongkar muat di pelabuhan. Dalam Keputusan Menteri Perhubungan Nomor KM 25 Tahun 2002 disebutkan bahwa tenaga kerja bongkar muat adalah semua tenaga kerja yang terdaftar pada pelabuhan setempat yang melakukan pekerjaan bongkar muat di pelabuhan.

Penerapan keselamatan kerja memiliki dasar hukum yaitu pada Undang-Undang Nomor 1 Tahun 1970 tentang keselamatan kerja, Undang-Undang Nomor 23 Tahun 1992 tentang kesehatan, dan UndangUdang Nomor 13 Tahun 2003 tentang ketenagakerjaan. Keselamatan kerja merupakan salah satu faktor yang mutlak harus dipenuhi agar tenaga kerja dapat bekerja dengan aman dan maksimal sesuai dengan tugas tenaga kerja, dengan sikap yang hati-hati dan tidak ceroboh dalam bertindak akan membuat pihak lain tidak mengalami kekhawatiran. Tetapi banyak tenaga kerja yang bekerja hanya sekedar memenuhi kewajiban sesuai tanggung jawabnya, tanpa memiliki kepedulian terhadap keselamatan orang lain, lingkungan sekitar, dan bahkan diri sendiri. Tingkat penggunaan alat keselamatan sangat berpengaruh pada tingkat keselamatan kerja. Semakin rendah frekuensi penggunaan alat keselamatan maka semakin besar terjadinya kecelakaan kerja dan berdampak pada kelancaran aktivitas proses bongkar muat. Di dalam proses bongkar muat penggunaan alat keselamatan sangatlah diperlukan, karena alat keselamatan kerja merupakan suatu alat yang dipakai untuk melindungi diri terhadap bahaya resiko kecelakaan kerja.

Masalah yang paling menonjol adalah tingkat penggunaan alat keselamatan kerja yang belum terlaksana secara optimal pada saat kegiatan bongkar muat di Pelabuhan Khusus PT. Semen Indonesia Tuban, masih ditemukan tenaga kerja bongkar muat yang tidak menggunakan alat keselamatan pada saat proses bongkar muat.

\section{METODOLOGI}

Metode yang digunakan pada pelitian ini yaitu menggunakan metode deskriptif kualitatif. Deskriptif kualitatif adalah tulisan yang berisi pemaparan, uraian dan penjelasan tentang suatu objek sebagaimana adanya pada waktu tertentu dan mengambil kesimpulan yang berlaku secara umum dengan tujuannya untuk mengungkapkan kejadian atau fakta, keadaan yang terjadi saat penelitian berlangsung dengan menyajikan apa yang terjadi, melakukan pengamatan terhadap permasalahan, kemudian dijabarkan secara terperinci dan dianalisa penyebab dan pemecahan masalahnya. Untuk mendapatkan sumber data dalam penelitian ini dilakukan dengan menggunakan observasi, wawancara, dokumentasi, dan juga metode kepustakaan.

Menurut Sarwono (2008:239), prinsip pokok teknik analisis ialah mengolah dan menganalisis data-data yang terkumpul menjadi data yang sistematik, teratur, terstruktur, dan mempunyai makna. Teknik analisis data yang akan digunakan oleh peneliti yaitu analisis Fishbone dan Fault Tree Analysis. Pengertian analisis fishbone adalah teknik analisa data dengan diagram tulang ikan yang menunjukan sebuah dampak atau akibat dari sebuah permasalahan dengan berbagai penyebabnya, kemudian efek atau akibat dituliskan sebagai moncong kepala ikan sedangkan tulang ikan diisi oleh sebabsebab sesuai dengan pendekatan permasalahannya. Teknik analisa data Fault Tree Analysis adalah suatu analisis data untuk mengidentifikasikan permasalahan yang dilakukan dengan pendekatan bersifat top down, diawali asumsi permasalahan (top event) kemudian merinci sebab top event sampai pada permasalahan dasar (root cause). 


\section{HASIL DAN DISKUSI}

\section{Bagaimana pelaksanaan penggunaan} alat keselamatan kerja terhadap tenaga kerja bongkar muat di Pelabuhan Semen Indonesia Tuban?

Penulis mengadakan observasi langsung ke Pelabuhan Khusus Semen Indonesia Tuban dan kemudian melakukan wawancara dengan pihak pelabuhan yaitu pengawas keselamatan pelabuhan dan beberapa tenaga kerja bongkar muat di pelabuhan. Dari hasil wawancara penulis mendapatkan gambaran bagaimana pelaksanaan penggunaan alat keselamatan kerja pada tenaga kerja bongkar muat saat proses bongkar muat di Pelabuhan Semen Indonesia Tuban.

Dari keterangan pengawas Pelabuhan Semen Indonesia Tuban dan tenaga kerja bongkar muat dapat disimpulkan bahwa pihak Pelabuhan memberikan tindakan preventif membagikan alat keselamatan kepada tenaga kerja dan memasang rambu-rambu pemakaian alat keselamatan pada gate pelabuhan. Tetapi tenaga kerja dalam melaksanakan bongkar muat sering tidak menggunakan alat keselamatan dikarenakan anggapan alat keselamatan menghalangi pekerjaan, kemudian karena tidak ada tindakan tegas dari pihak Pelabuhan Semen Indonesia Tuban menyebabkan tenaga kerja bongkar muat tidak melaksanakan aturan yang sudah ada, dan karena rendahnya tingkat kesadaran tenaga kerja tentang risiko bahaya yang ditimbulkan apabila tidak menggunakan alat keselamatan kerja pada saat bekerja.

\section{Bagaimana dampak yang ditimbulkan} dari kurangnya penggunaan alat keselamatan kerja tenaga kerja bongkar muat pada proses bongkar muat di Pelabuhan Semen Indonesia Tuban?

Dalam menentukan dampak terlebih dahulu menentukan faktor yang menyebabkan kurang optimalnya penggunaan alat keselamatan. Dalam hal ini menggunakan fishbone analysis untuk menjabarkan faktor penyebab, yaitu:
a. Manusia (Man);
b. Peralatan (Equipment);
c. Aturan (Rule);
d. Lingkungan (Environment).

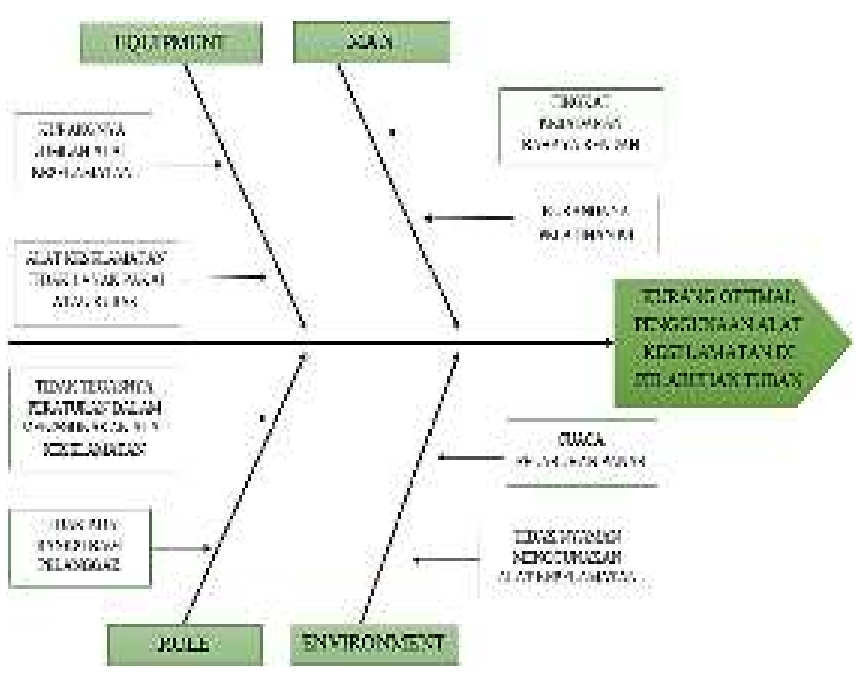

Gambar Diagram Fishbone Analysis

a) Manusia (Man)

Salah satu faktor yang menyebabkan kurang optimalnya penggunaan alat keselamatan kerja pada tenaga kerja bongkar muat adalah rendahnya tingkat kesadaran tenaga kerja bongkar muat dalam menggunakan alat keselamatan kerja serta kurangnya pelatihan tentang keselamatan dan kecelakaan kerja. Kesadaran adalah sikap secara sukarela menaati peraturan dan sadar tugas serta tanggung jawabnya.

Setelah melakukan observasi langsung masih ditemukan tenaga kerja tidak menggunakan alat keselamatan kerja, hal ini menimbulkan terjadi kecelakaan kerja mengakibatkan tenaga kerja tidak dapat bekerja sementara waktu, maka menyebabkan berkurang penghasilan bagi tenaga kerja tersebut. Dalam hal ini membuat berkurangnya tenaga kerja untuk kegiatan bongkar muat tersebut, maka perlu pengganti bagi tenaga kerja yang mengalami 
kecelakaan. Dalam proses penggantian tenaga kerja memerlukan waktu, karena adanya insiden kecelakaan kerja maka menyebabkan keterlambatan dalam hal bongkar muat semen di Pelabuhan Semen Indonesia Tuban.

b) Peralatan (Equipment)

Tenaga kerja bongkar muat adalah salah satu faktor penting dalam menunjang proses bongkar muat di pelabuhan. Semakin banyak jumlah tenaga kerja yang bekerja semakin berjalan cepat proses bongkar muat tersebut. Di Pelabuhan Semen Indonesia Tuban menerapkan sistem dimana setelah pemakaian alat keselamatan tenaga kerja bongkar muat diharuskan merawat dan menjaga alat keselamatan kerja yang telah dibagikan pihak pengawas pelabuhan agar dapat bertahan lama dan berfungsi dengan baik. Namun di lapangan setelah dibagikan alat keselamatan kerja dirasa masih belum berjalan optimal sejauh pengamatan penulis. Pentingnya alat keselamatan diabaikan tenaga kerja bongkar muat saat bekerja. Di Pelabuhan Semen Indonesia Tuban ketersediaan jumlah alat keselamatan belum sesuai dengan jumlah tenaga kerja bongkar muat, sehingga penggunaan alat keselamatan masih belum optimal. Alat keselamatan yang sudah tidak layak pakai atau rusak juga merupakan faktor penyebab masih ditemukan tenaga kerja yang tidak menggunakan alat keselamatan kerja lengkap pada saat melaksanakan proses bongkar muat. Tidak optimalnya penggunaan alat kesematan kerja pada tenaga kerja dapat menimbulkan risiko bahaya kecelakaaan kerja, seperti contoh yaitu tenaga kerja tertimpa semen atau tergelincir jatuh. Hal ini dibuktikan dengan observasi disertai dokumen gambar yang penulis ambil langsung dari Pelabuhan Semen Indonesia Tuban.

c) Aturan (Rule)

Faktor selanjutnya yang menyebabkan kurang optimalnya penggunaan alat keselamatan kerja pada tenaga kerja bongkar muat di Pelabuhan Semen Indoneisa Tuban adalah tidak adanya sanksi yang diberikan bagi tenaga kerja bongkar muat yang tidak menggunakan alat keselamatan kerja. Penggunaan alat keselamatan kerja merupakan hal penting bagi setiap orang yang melakukan pekerjaan. Aturan penggunaan alat keselamatan kerja dibuat untuk mengatur dan mengarahkan para pekerja untuk selalu memperhatikan kesehatan dan keselamatannya saat melaksanakan pekerjaan. Dengan adanya peraturan yang ditetapkan diharapkan para pekerja dapat mengindahkannya sehingga angka kecelakaan kerja dapat diminimalisir oleh pihak pelabuhan.

Peraturan tentang Kesehatan dan Keselamatan Kerja terdapat pada UU No. 1 Tahun 1970 tentang Kselamatan Kerja, UU No. 23 Tahun 1992 tentang Kesehatan Kerja, UU No. 12 Tahun 2003 tentang Ketenagakerjaan. Di Pelabuhan Semen Indonesia belum terdapat peraturan yang tegas mengatur penggunaan alat keselamatan kerja, sehingga belum ada sanksi bagi yang melanggar. Hal ini dilakukan supaya merasa jera apabila melanggar peraturan, sehingga mereka akan tetap terdorong untuk menggunakan alat keselamatan kerja dan mematuhi peraturan yang dibuat. Tidak hanya dengan pemberian sanksi bagi tenaga kerja bongkar muat yang melakukan pelanggaran, tetapi juga dengan pemberian reward kepada mereka yang patuh terhadap peraturan yang 
sudah ditentukan dengan menggunakan alat keselamatan kerja.

d) Lingkungan (Environment)

Penyebab kurang optimalnya penggunaan alat keselamatan adalah faktor lingkungan. Lingkungan merupakan faktor yang memengaruhi penggunaan alat keselamatan pada tenaga kerja di pelabuhan. Selama melaksanakan observasi di Pelabuhan Semen Indonesia Tuban, menemukan tenaga kerja yang tidak menggunakan alat keselamatan. Alasan tidak mengunakan alat keselamatan adalah cuaca di pelabuhan yang panas pada saat siang saat mereka melakukan proses bongkar muat, hal itu membuat tidak nyaman tenaga kerja dalam menggunakan alat keselamatan dapat menimbulkan risiko kecelakaan kerja, yang dapat mempengaruhi jadwal bongkar muat. Jadwal bongkar muat berubah karena seharusnya bongkar muat dapat diselesaikan dalam waktu yang sudah ditentukan namun terjadinya kecelakaan menyebabkan perubahan pula pada jadwal proses bongkar muat di pelabuhan. Perubahan jadwal juga dapat menimbulkan dampak lain yaitu terhambat proses produksi semen di pelabuhan. Terjadinya keterlambatan dalam proses produksi semen yang merupakan akibat dari adanya kecelakaan kerja pada tenaga kerja bongkar muat yang tidak menggunakan alat keselamatan kerja.

\section{Bagaimana upaya yang dilakukan untuk mengatasi kurangnya penggunaan alat keselamatan kerja tenaga kerja bongkar muat pada proses bongkar muat di Pelabuhan Semen Indonesia Tuban?}

Dalam mengoptimalkan penggunaan alat keselamatan terhadap tenaga kerja bongkar muat di Pelabuhan Semen Indonesia Tuban, maka perlu dilakukan upaya untuk mengatasi permasalahan, peneliti menganalisa kembali penyebab permasalahan yang sudah didapat melalui metode fishbone analysis dengan menggunakan metode Fault Tree Analysis (FTA). Tujuannya adalah untuk mendapatkan akar penyebab permasalahan tersebut, sehingga nantinya dapat diketahui upaya yang harus dilakukan mengatasi kurang optimalnya penggunaan alat keselamatan kerja.

a. Manusia (Man)

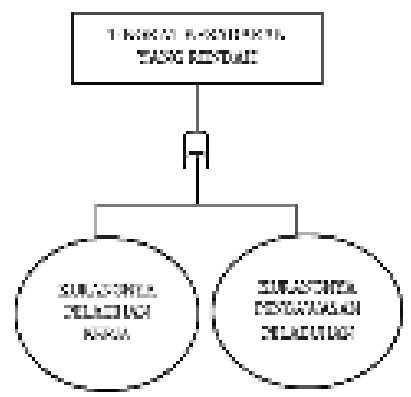

\section{Gambar Pohon Kesalahan 1}

Dari gambar di atas, kurang optimalnya penggunaan alat keselamatan kerja terhadap kerja tenaga kerja bongkar muat pada proses bongkar muat di Pelabuhan Semen Indonesia Tuban disebabkan oleh kurangnya pelatihan kerja prosedur penggunaan alat keselamatan kerja maupun pelatihan bahaya kecelakaan kerja, pelatihan merupakan penunjang untuk optimalnya penggunaan alat keselamatan kerja. Selain kurangnya pelatihan, kurangnya pengawasan dari pihak pelabuhan dan tidak adanya pengecekan secara berkala pada saat proses bongkar muat menjadi faktor penyebab berikutnya. Pengawasan dilakukan pada saat kegiatan kerja sehingga semua kegiatan dapat dikontrol dengan baik dan benar sesuai dengan prosedur yang ada. Selain kurangnya pelatihan, kurangnya pengawasan dari pihak pelabuhan dan tidak adanya pengecekan secara berkala pada saat proses bongkar muat menjadi faktor penyebab berikutnya. Pengawasan dilakukan pada saat kegiatan kerja 
sehingga semua kegiatan dapat dikontrol dengan baik dan benar sesuai dengan prosedur yang ada. Tindakan kontrol lebih baik dilakukan sebelum terjadi penyimpangan sehingga bersifat mencegah (preventif) dibandingkan tindakan sesudah terjadi penyimpangan (repressive).

Berdasarkan kesimpulan kurang optimalnya penggunaan alat keselamatan kerja yang disebabkan karena rendahnya tingkat kesadaran tenaga kerja, maka upaya yang dilakukan adalah pihak Pelabuhan Semen Indonesia Tuban mengadakan penyuluhan sekaligus pelatihan tentang bahaya kecelakaan kerja di tempat bongkar muat dan keselamatan kecelakaan kerja bagi tenaga kerja bongkar muat.

\section{b. Peralatan (Equipment)}

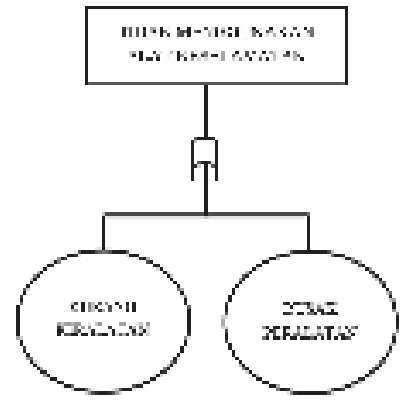

\section{Gambar Pohon Kesalahan 2}

Keselamatan kerja merupakan salah satu faktor yang mutlak yang harus dipenuhi agar tenaga kerja dapat bekerja dengan aman dan dapat bekerja dengan maksimal. Banyak tenaga kerja yang bekerja hanya sekedar memenuhi kewajiban sesuai tanggung jawabnya, tanpa memiliki kepedulian terhadap keselamatan diri sendiri, orang lain dan lingkungan. Tingkat penggunaan alat keselamatan kerja sangat berpengaruh pada tingkat keselamatan kerja. Semakin rendah frekuensi penggunaan alat keselamatan kerja maka semakin besar kesempatan terjadinya kecelakaan kerja dan berdampak pada kelancaran kegiatan kerja di Pelabuhan Semen Indonesia Tuban.

Berdasarkan observasi, faktor lain dari kurang optimalnya penggunaan alat keselamatan adalah ketidaksesuain jumlah tenaga kerja dengan jumlah alat keselamatan yang disediaan oleh pihak Pelabuhan Semen Indonesia Tuban. Penggunaan alat keselamatan tidak sesuai prosedur, misalnya adalah tenaga kerja menggunakan safety shoes tetapi mereka tidak menggunakan safety helm serta tidak menggunakan masker wajah sesuai prosedur alat keselamatan tetapi menggunakan kaos yang diikatkan pada wajah mereka untuk menutupi wajah dari panas dan menghindari debu dari muatan yang di bongkar. Penambahan jumlah alat keselamatan kerja oleh pihak pelabuhan menjadi salah satu upaya untuk mengoptimalkan penggunaan alat keselamatan kerja pada tenaga kerja bongkar muat. Dengan tersedianya jumlah alat keselamatan kerja yang sesuai dengan jumlah tenaga kerja maka tenaga kerja bongkar muat di pelabuhan tidak perlu berebut dalam menggunakan alat keselamatan kerja tersebut.

c. Aturan (Rule)

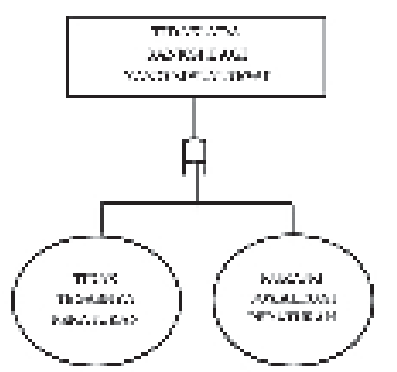

Gambar Pohon Kesalahan 3

Peraturan mempunyai pengaruh sebagai penyebab kurang optimalnya penggunaan alat keselamatan kerja pada tenaga kerja bongkar muat di 
Pelabuhan Semen Indonesia Tuban. Dengan adanya peraturan yang ditetapkan diharapkan para pekerja dapat melaksanakannya sehingga angka kecelakaan kerja dapat diminimalisir.

Dari penelitian, faktor penyebab adalah tidak adanya sanksi yang tegas bagi tenaga kerja bongkar muat yang tidak menggunakan alat keselamatan kerja. Seharusnya sanksi digunakan untuk membuat efek jera pada pelanggar peraturan. Dan juga faktor lain dari tidak adanya sanksi bagi pelanggar adalah kurangnya sosialisasi tentang peraturan alat keselamatan kerja merupakan faktor lain dari tidak optimalnya penggunaan alat keselamatan kerja terhadap tenaga kerja bongkar muat di Pelabuhan Semen Indonesia Tuban. Maka, pihak pelabuhan harus melakukan penyuluhan tentang keselamatan dan kecelakaan kerja pada tenaga kerja bongkar muat. Hal ini merupakan salah satu upaya untuk mengenalkan tenaga kerja kepada peraturan penggunaan alat keselamatan kerja di pelabuhan Semen Indonesia Tuban guna menunjang bongkar muat.

\section{d. Lingkungan (Environment)}

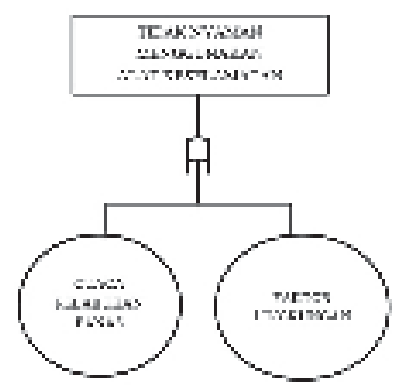

\section{Gambar Pohon Kesalahan 4}

Salah satu faktor penyebab kurang optimalnya penggunaan alat keselamatan kerja pada tenaga kerja bongkar muat adalah ketidaknyamanan dalam menggunakan alat keselamatan pada saat bekerja dengan kondisi cuaca di pelabuhan yang panas. Cuaca di pelabuhan yang panas membuat tenaga kerja bongkar muat memilih untuk tidak menggunakan alat keselamatan tersebut, hal ini dapat menimbulkan terjadinya kecelakaan kerja. Upaya yang harus dilakukan oleh pihak pelabuhan adalah dengan memberikan pengarahan kepada tenaga kerja setiap harinya pada saat sebelum memulai kegiatan proses bongkar muat. Pengarahan ini bertujuan untuk mengarahkan tenaga kerja untuk menggunakan alat keselamatan kerja selama proses bongkar muat untuk melindungi diri dari kecelakaan kerja yang tidak diinginkan.

Faktor penyebab berikutnya adalah dari faktor lingkungan. Lingkungan kerja yang kondusif memberikan rasa aman dan memungkinkan pekerja untuk dapat bekerja optimal. Lingkungan kerja diartikan sebagai kekuatan yang memengaruhi. Lingkungan kerja merupakan faktor yang mempengaruhi penggunaan alat keselamatan kerja pada tenaga kerja bongkar muat di pelabuhan. Tetapi ternyata rata-rata tenaga kerja lama bukannya menjadi contoh tetapi malah menjadi kurang disiplin dalam penggunaan alat keselamatan kerja pada saat proses bongkat muat berlangsung di pelabuhan. Tenaga kerja sudah lama bekerja lebih susah untuk diatur, karena menganggap halhal yang dilakukan mereka biasanya itu benar karena belum terjadi kecelakaan kerja, padahal yang terjadi saat ini adalah kebiasaan salah yang dilakukan secara terus-menerus. Sehingga mereka sering tidak melakukan yang sudah diinstruksikan oleh pihak pengawas pelabuhan tentang kewajiban penggunaan alat keselamatan kerja pada saat bekerja dan mereka memilih untuk melakukan proses bongkar muat 
tanpa menggunakan alat keselamatan kerja.

\section{PEMBAHASAN MASALAH}

\section{Bagaimana}

pelaksanaan

penggunaan alat keselamatan kerja terhadap tenaga kerja bongkar muat di Pelabuhan Semen Indonesia Tuban?

Keselamatan kerja merupakan salah satu faktor mutlak yang harus dipenuhi agar tenaga kerja dapat bekerja dengan aman dan maksimal. Di Pelabuhan Semen Indonesia Tuban masalah yang menonjol adalah penggunaan alat keselamatan kerja pada tenaga kerja bongkar muat saat proses bongkar muat belum terlaksana dengan optimal. Tingkat penggunaan alat keselamatan kerja berpengaruh pada tingkat keselamatan kerja. Semakin rendah frekuensi penggunaan alat keselamatan maka semakin besar kesempatan terjadinya kecelakaan kerja dan akan berdampak pada kelancaran proses bongkar muat di Pelabuhan Khusus Semen Indonesia Tuban. Selama kegiatan bongkar muat penggunaan alat keselamatan kerja yang wajib digunakan oleh tenaga kerja bongkar muat adalah safety helmet, safety shoes, masker, rompi, dan sarung tangan.

2. Bagaimana dampak yang ditimbulkan dari kurangnya penggunaan alat keselamatan kerja tenaga kerja bongkar muat pada proses bongkar muat di Pelabuhan Semen Indonesia Tuban?

a. Bagi (TKBM)

1) Tidak terjaminnya kesehatan dan keselamatan kerja

Tenaga kerja bongkar muat yang tidak mengunakan alat keselamatan menyebabkan kecelakaan kerja, baik cidera ringan atau berat memerlukan biaya perawatan, tetapi pihak pelabuhan hanya memberikan pertolongan pertama kecelakaan kerja pada proses bongkar muat. Maka dampak yang ditimbulkan adalah tidak ada jaminan pihak pelabuhan akan kesehatan dan keselamatan kerja tenaga kerja bongkat muat tersebut.

2) Meningkatnya risiko kecelakaan kerja

Rendah tingkat kesadaran tenaga kerja bongkar muat dalam menggunakan alat keselamatan kerja pada saat proses bongkar muat, hal ini menyebabkan meningkatnya risiko terjadinya kecelakaan kerja dan hal ini memiliki dampak langsung terhadap kelancaran dari proses bongkar muat di Pelabuhan Semen Indonesia Tuban.

3) Berkurangnya sumber pendapatan tenaga kerja

Dengan terjadinya kasus kecelakaan kerja yang disebabkan oleh tenaga kerja bongkar muat tidak menggunakan alat keselamatan ketika berada di pelabuhan yang mengakibatkan tenaga kerja bongkar muat tersebut tidak dapat bekerja untuk sementara waktu, maka menyebabkan berkurangnya penghasilan atau hilangnya sumber pendapatan dari tenaga kerja tersebut.

b. Bagi pihak pelabuhan

1) Berubah jadwal bongkar muat

Kecelakaan kerja yang terjadi pada tenaga kerja bongkar muat akan berdampak pada jadwal bongkar muat di Pelabuhan Semen Indonesia Tuban. Dengan adanya kecelakaan kerja 
mengakibatkan cidera pada tenaga kerja bongkar muat, otomatis berkurangnya tenaga kerja yang melakukan aktivitas bongkar muat maka hal ini bisa menggangu kegiatan bongkar muat dan bahkan menghambat proses bongkar muat. Hal ini menyebabkan kemunduran waktu proses bongkar muat semen atau terjadi penambahan waktu untuk proses bongkar muat di Pelabuhan Semen Indonesia Tuban.

2) Lambatnya dalam replacement tenaga kerja baru

Kecelakaan kerja terjadi pada tenaga kerja yang tidak menggunakan alat keselamatan, mengakibatkan tenaga kerja tersebut tidak dapat melaksanakan bongkar muat. Dalam hal ini, maka perlu ada pengganti untuk tenaga kerja yang mengalami kecelakaan. Proses penggantian tenaga kerja tidak dapat dilaksanakan dengan cepat memerlukan waktu. Hal ini menghambat dan memperlambat dalam proses bongkar muat semen di pelabuhan.

3) Terhambat dalam proses produksi semen

Kerugian yang dialami pihak pelabuhan adalah terhambatnya produksi semen dikarenakan terlambatnya bongkar muat. Adanya kecelakaan membuat berkurang tenaga kerja untuk bongkar muat. Dengan berkurangnya tenaga kerja menimbulkan kesulitan pihak pelabuhan mencari pengganti tenaga kerja bongkar muat, karena adanya insiden ini menyebabkan keterlambatan bongkar muat di
Pelabuhan Semen Indonesia Tuban.

3. Bagaimana upaya yang dilakukan untuk mengatasi kurangnya penggunaan alat keselamatan kerja tenaga kerja bongkar muat pada proses bongkar muat di Pelabuhan Semen Indonesia Tuban?

a. Melakukan koordinasi dalam mengawasi dan mengontrol aktifitas tenaga kerja bongkar muat

Pihak keamanan pelabuhan harus melakukan koordinasi yang baik dalam mengawasi dan mengontrol aktifitas tenaga kerja, agar pelanggaran dalam penggunaan alat keselamatan kerja dapat diminimalisir. Apabila terjadi pelanggaran oleh tenaga kerja bongkar muat dengan tidak menggunakan alat keselamatan kerja, maka pihak pengawas pelabuhan dapat memberikan sanksi sesuai dengan prosedur aturan yang telah ditetapkan oleh pelabuhan. Melakukan pengawasan terhadap tenaga kerja bongkar muat pada saat proses bongkar muat berlangsung di pelabuhan merupakan salah satu cara efektif untuk mengoptimalkan penggunaan alat keselamatan pada tenaga kerja bongkar muat guna menunjang proses bongkar muat di Pelabuhan Semen Indonesia Tuban.

b. Memasang rambu-rambu peringatan dan penambahan alat keselamatan kerja di pelabuhan

Pelabuhan Semen Indonesia Tuban harus menjalankan usaha preventif untuk mencegah terjadinya kecelakaan kerja yaitu memasang rambu peringatan penggunaan alat keselamatan kerja yang dipasang di tempat yang mudah dilihat seperti di gate masuk pelabuhan. Dan juga upaya 
yang harus dilakukan oleh pihak Pelabuhan Semen Indonesia Tuban dalam mengoptimalkan penggunaan alat keselamatan kerja pada tenaga kerja adalah dengan penambahan alat keselamatan kerja untuk tenaga kerja bongkar muat. Dimana dalam penambahan alat keselamatan harus ada kesesuaian antara jumlah alat keselamatan yang digunakan tenaga kerja dengan jumlah tenaga kerja yang bekerja dalam proses bongkar muat di Pelabuhan Semen Indonesia Tuban.

c. Melakukan pelatihan tentang Kesehatan dan Keselamatan Kerja (K3) dan penyuluhan peraturan bagi para tenaga kerja bongkar muat

Yang dimaksudkan adalah pihak Pelabuhan Semen Indonesia Tuban melakukan pelatihan Kesehatan dan Keselamatan Kerja (K3) dan penyuluhan peraturan bagi para tenaga kerja bongkar muat dengan mengundang narasumber yang ahli. Pelatihan penyuluhan dimaksudkan agar tenaga kerja mengerti kaidah dan meningkatkan kesadaran tenaga kerja bahaya yang timbul dari kurang optimalnya penggunaan alat keselamatan kerja. Dengan diberikannya pelatihan kesehatan dan keselamatan kerja tenaga kerja akan lebih memahami mengenai bahaya kecelakaan kerja serta pentingnya keselamatan kerja dan pelatihan tersebut mempengaruhi perilaku tenaga kerja bongkar muat. Selain diberikan pelatihan mengenai kesehatan dan keselamatan kerja, pihak pelabuhan juga harus memberikan penyuluhan kepada tenaga kerja mengenai peraturan penggunaan alat keselamatan kerja. d. Melaksanakan safety meeting sebelum kegiatan bongkar muat

Yang dimaksudkan adalah pihak pengawas memberikan pengarahan tenaga kerja bongkar muat yang akan melaksanakan proses bongkar muat di Pelabuhan Semen Indonesia Tuban dan emberikan alat keselamatan kerja seperti safety helmet, safety shoes, sarung tangan dan masker wajah. Hal ini menghindari kecelakaan kerja dengan memberikan pengetahuan tentang risiko bahaya yang mungkin terjadi saat proses bongkar muat tersebut. Untuk itu diperlukan pencegahan dan penanggulangan risiko bahaya dari kecelakaan kerja dengan melaksanakan pengarahan atau (safety meeting) kepada tenaga kerja bongkar muat sebelum kegiatan proses bongkar muat di pelabuhan berlangsung, hal ini dilakukan untuk mengoptimalkan penggunaan alat keselamatan kerja pada tenaga kerja bongkar muat pada saat proses bongkar muat di Pelabuhan Semen Indonesia Tuban

\section{KESIMPULAN}

Berdasarkan penelitian mengenai penggunaan alat keselamatan terhadap tenaga kerja di Pelabuhan Semen Indonesia Tuban, maka penulis mengambil kesimpulan, yaitu:

1. Penggunaan alat keselamatan kerja terhadap tenaga kerja bongkar muat guna menunjang proses bongkar muat di Pelabuhan Semen Indonesia Tuban belum terlaksana dengan optimal. Masih terdapat tenaga kerja tidak menggunakan alat keselamatan pada saat bongkar muat. Hal ini disebabkan karena beberapa faktor yang mempengaruhi yaitu rendahnya tingkat kesadaran tenaga kerja bongkar muat, ketidaksesuaian jumlah alat keselamatan 
yang disediakan pihak pelabuhan, tidak ada sanksi karena kurang tegasnya peraturan, dan rasa ketidaknyamanan tenaga kerja dalam menggunakan alat keselamatan kerja.

2. Dampak yang ditimbulkan dari kurang optimalnya penggunaan alat keselamatan sebagai berikut yaitu:

a. Bagi TKBM

1) Tidak terjaminnya kesehatan dan keselamatan tenaga kerja;

2) Meningkatnya risiko terjadi kecelakaan kerja;

3) Berkurangnya sumber pendapatan tenaga kerja.

b. Bagi pihak pelabuhan

1) Adanya perubahan jadwal proses bongkar muat di pelabuhan;

2) Lambatnya pada proses replacement tenaga kerja yang baru;

3) Terhambatnya proses produksi semen di pelabuhan.

3. Upaya yang dilakukan untuk mengatasi kurang optimalnya penggunaan alat keselamatan di Pelabuhan Semen Indonesia Tuban adalah sebagai berikut, yaitu:

a. Melaksanakan koordinasi dan komunikasi terhadap pengawasan aktifitas tenaga kerja bongkar muat;

b. Memasang rambu peringatan dalam menggunakan alat keselamatan;

c. Melakukan pelatihan tentang kesehatan dan keselamatan kerja;

d. Melaksanakan pengarahan safety meeting kepada tenaga kerja.

\section{DAFTAR PUSTAKA}

Keputusan Menteri Perhubungan. Nomor KM 25 tahun 2002 tentang Pedoman Dasar Perhitungan Tarif Pelayanan Jasa Bongkar Muat Barang Dari dan Ke Kapal di Pelabuhan

Mardalis. 2008. Metode Penelitian Suatu Pendekatan Proposal. Jakarta : Bumi Aksara
Margono S. 2007. Metologi Penelitian Pendidikan Komponen MKDK. Jakarta : PT. Rineka Cipta

Peraturan Menteri Perhubungan Pasal 14 Undang-Undang Nomor 1 Tahun 1970 Tentang Keselamatan dan Kesehatan Kerja

Peraturan Menteri Tenaga Kerja dan Transmigrasi Republik Indonesia Nomor Per.08/MEN/VII/2010

Priyanta, Dwi. 2000. Keandalan Dan Perawatan. Surabaya : Institut Teknologi Surabaya

Ridley, Jhon. 2009. Kesehatan dan Keselamatan Kerja. Jakarta : Erlangga

Sucipto, Cecep Dani. 2014. Keselamatan dan Kesehatan Kerja. Yogyakarta : Gosyen Publishing

Sugiyono. 2013. Metode Penelitian Pendidikan Pendekatan Kuantitatif, Kualitatif dan R\&D. Bandung : Alfabeta

Sukmadinata, Nana Syaodih. 2013. Metode Penelitian Pendidikan. Bandung : PT. Remaja Rosdakarya

Sarwono, Jonathan. 2008. Metode Penelitian Kuantitatif dan Kualitatif. Yogyakarta : Graha Ilmu

Undang-Undang Republik Indonesia Nomor 13 Tahun 2003 tentang Ketenagakerjaan

Undang-Undang Republik Indonesia Nomor 1 Tahun 1970 tentang Keselamatan Kerja

https://sistemmanajemenkeselamatankerja. blogspot.co.id

http://wardanasl.blogspot.co.id/2012/07/pe ngertian-alat-pelindung-diriapd.html 